\title{
Correction: Developing a globally applicable evidence- informed competency framework to support capacity strengthening in clinical research
}

Julé A, Furtado T, Boggs L, et al. Developing a globally applicable evidenceinformed competency framework to support capacity strengthening in clinical research. BMJ Global Health 2017;2:e000229.

In the competing interests section the following statement: 'The Global Health Network is funded by the Bill and Melinda Gates Foundation' incorrectly infers that the Bill \& Melinda Gates foundation is the sole funder. This is inaccurate and should read: 'The Global Health Network is funded in part by a grant from the Bill \& Melinda Gates Foundation.'

Open Access This is an Open Access article distributed in accordance with the Creative Commons Attribution Non Commercial (CC BY-NC 4.0) license, which permits others to distribute, remix, adapt, build upon this work non-commercially, and license their derivative works on different terms, provided the original work is properly cited and the use is non-commercial. See: http://creativecommons.org/licenses/by-nc/4.0/

(c) Article author(s) (or their employer(s) unless otherwise stated in the text of the article) 2017. All rights reserved. No commercial use is permitted unless otherwise expressly granted.

BMJ Glob Health 2017;2:e000229corr1. doi:10.1136/bmjgh-2016-000229corr1

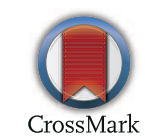

